\section{Informasjonskaos om angst}

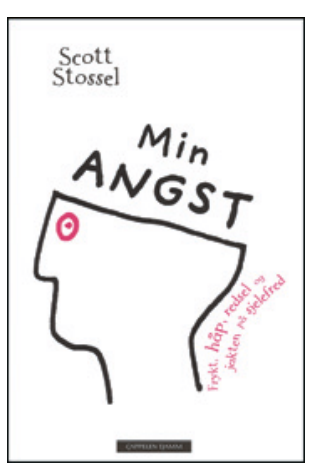

Scott Stossel

Min angst

Frykt, håp, redsel og jakten på sjelefred. $396 \mathrm{~s}$.

Oslo: Cappelen Damm, 2015. Pris NOK 399

ISBN 978-82-02-47151-4

Scott Stossel er redaktør av The Atlantic Magazine, og hans bok om angst har vært på bestselgerlisten til The New York Times. Dette antyder at den amerikanske kultureliten er målgruppen for denne utgivelsen, og man kan spørre seg om hvor relevant den er for norske leger.

Boken formidler tre aspekter: angstens historie, angst hos Stossel og hans familie og forskningsfunn om angst. Disse aspektene blandes stadig sammen, så leseren må være observant. For eksempel glir presentasjonen av bestefars angst sømløst over i hva Robert Burton (1577-1640) mente om angsten, som så blir fulgt av nyere forskningsfunn. Stossel beskriver omfattende sin egen angst og ulike behandlinger han har fått, og man spør seg uvilkårlig om hvordan han kan greie en krevende redaktørjobb med et så massivt symptomtrykk.

Henger man med i svingene, får man mye informasjon om angst, siden Stossel har lest en masse, minst 100000 artikler, ifølge ham selv. Spørsmålet er om han har lest med et kritisk blikk? Han angir stadig hva studier har vist, men vurderer aldri studiekvaliteten.

Et annet problem er at Stossel stadig biter den hånden som mater ham. Han kritiserer Freud og psykoanalytikerne, men omtaler seg selv og andre som nevrotikere. Han gjør narr av atferdsterapeutene, men utsetter seg likevel for eksponering. Som så mange kritiserer han DSM-III/DSM-5-klassifikasjonene for den kriteriebaserte diagnostikken, uten å komme med noe bedre alternativ. Den farmasøytiske industrien får gjennomgå for å skape psykiske lidelser ut fra profittbegjær, men Stossel selv er fortapt uten piller.

Dessverre har forlaget valgt en ordrett oversettelse. Det er irriterende at alle medisiner angis med amerikanske salgsnavn istedenfor norske, og at medikamenter som ikke blir markedsført i Norge også er med. Stossel er utvilsomt en informasjonsrik amatør som har gjort seg mange tanker om angst, men for den som kan angstlidelser, er det lett å påvise mengder av faktafeil. Biologisk reduksjonisme, som «nervøs amygdala» og lignende, florerer. Oversetteren synes ikke å være velkjent med angstfeltet, det bidrar til en rekke trykkfeil og amerikanismer. For meg er det uklart hva de 400 sidene egentlig kan tilføre norske allmennleger og psykiatere.

\section{Alv A. Dahl}

Forskningsrådgiver, Nasjonal kompetansetjeneste for seneffekter etter kreftbehandling

Oslo universitetssykehus, Radiumhospitalet

\section{Den psykisk syke kroppen}

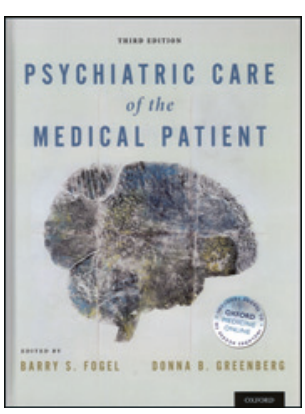

Barry S. Fogel, Donna B. Greenberg Psychiatric care of the medical patient 3. utg. $1812 \mathrm{~s}$, tab, ill. Oxford: Oxford University Press, 2015. Pris GBP 163 ISBN 978-0-19-973185-5

Det er økt forekomst av psykiske lidelser hos personer med legemlige sykdommer. Samtidig ubehandlet psykisk lidelse kan komplisere forløpet av den somatiske sykdommen og i noen tilfeller til og med føre til høyere dødelighet. Adekvat diagnostikk og behandling av psykiske lidelser ved samtidig somatisk sykdom er derfor meget viktig. Det krever imidlertid ikke bare gode kunnskaper i psykiatri, det trengs også kunnskaper om hvordan den somatiske sykdommen kan innebære at den psykiatriske behandlingen må justeres i forhold til hvordan den ville vært hvis det «bare» forelå en psykisk lidelse. Denne utgivelsen er en av flere fra de siste par år som omhandler dette fagområdet. Målgruppen er leger som arbeider med slike problemstillinger.

Dette er en murstein av en oppslagsbok - den består av ti deler med til sammen 88 kapitler. Det er både generelle kapitler om f.eks. psykofarmakologi og psykososiale behandlinger ved legemlige sykdommer så vel som en rekke kapitler om psykiatrisk behandling av ulike sykdomsgrupper som øre-nese-hals-sykdommer, hjerte- og karsykdommer og nevrologiske sykdommer. Hvert kapittel ender med en kort stikkordsmessig oppsummering av de viktigste fakta.

Kvaliteten på og omfanget av de enkelte kapitlene er variabel. Kapitlet om delirium er for eksempel svært godt og dyptpløyende, med 574 referanser, men neppe egnet som introduksjon til temaet. Kapitlene om psykiatriske aspekter ved øre-nese-hals-sykdommer og blod- og infeksjonssykdommer er eksempler på mye kortere, men likevel gode gjennomganger. Andre kapitler er svakere, f.eks. det om gynekologi og graviditet og problemer etter fødselen. Det er underlig at det ikke er noe kapittel om psykiatriske aspekter ved ulykker og kirurgiske skader. Derimot er det i kapitlet om dermatologi omtale av eksessiv solbruning (tanning), som av forfatterne anføres å være et klinisk problem med psykiatriske implikasjoner et fenomen som nok er litt fremmed for oss nordmenn.

Den ensidige vektlegging av amerikanske forhold, også hva gjelder henvisning til forskning, er en klar svakhet. Ikke minst når det kommer til bruk av psykofarmaka og psykometriske metoder får dette betydning. For eksempel omtales kun karbonatformen av litium, og den brukes ikke i Norge. I hovedkapitlet om psykofarmaka omtales ikke escitalopram, mianserin eller lurasidon, men f.eks. nefazodon og trazodon, som er avregistrert/ikke registrert hos oss. Mye brukte skalaer som f.eks. Montgomery og Åsbergs depresjonsskala (MADRS) eller MINI nevropsykiatrisk intervju omtales heller ikke, til gjengjeld nevnes flere eldre skalaer som kun brukes i USA. Omtale av undersøkelser med et mer psykologisk perspektiv glimrer stort sett med sitt fravær. Dette er ingen bok for den allment interesserte lege. Den vil først og fremst være til nytte som støttelitteratur for leger som allerede kan mye om fagområdet.

Ulrik Fredrik Malt

Professor, Institutt for klinisk medisin Universitetet i Oslo 